Tropical Journal of Pharmaceutical Research January 2018; 17 (1): 127-134

ISSN: $1596-5996$ (print); 1596-9827 (electronic) (C) Pharmacotherapy Group, Faculty of Pharmacy, University of Benin, Benin City, 300001 Nigeria.

\title{
Synthesis, biological evaluation and molecular docking studies of Mannich bases derived from 1, 3, 4-oxadiazole- 2-thiones as potential urease inhibitors
}

\author{
Muhammad Akram ${ }^{1 \star}$, Abdul Rauf ${ }^{1 \star}$, Aamer Saeed ${ }^{2}$, Faiz Ahmed ${ }^{1}$, Sidra \\ Mubeen ${ }^{1}$, Muhammad Ashraf ${ }^{1}$, Safdar Hussain ${ }^{1}$, Ashfaq Mahmood Qureshi ${ }^{3}$ \\ ${ }^{1}$ Department of Chemistry, The Islamia University of Bahawalpur, Bahawalpur - 63100, ${ }^{2}$ Department of Chemistry, Quaid-i- \\ Azam University, Islamabad - 45320, ${ }^{3}$ Institute of Chemical Sciences, Bahauddin Zakariya University, Multan - 60800, Pakistan
}

*For correspondence: Email: lecorganic@yahoo.com, shamashfaq@yahoo.com; Tel: +92-3006828250, +92-3338863632

\begin{abstract}
Purpose: To design and synthesize a series of new structural motifs of urease inhibitors, 3[\{(substituted phenyl) amino\} methyl]-5-(3, 4, 5-trimethoxyphenyl)-1,3,4-oxadiazole-2(3H)-thiones and 3$\{[($ pyridin-2-yl)amino]methy|\}-5-(3,4,5-trimethoxy phenyl)-1,3,4-oxadiazole-2(3H)-thiones from 1, 3, 4oxadiazole-2-thione.

Methods: Targeted Mannich base derivatives were synthesized by the reaction of 1, 3, 4-oxadiazole-2thione with formaldehyde and respective aromatic amines. These structural motifs were subjected to ${ }^{1} \mathrm{H}-\mathrm{NMR},{ }^{13} \mathrm{C}-\mathrm{NMR}$ and mass spectrometric analysis. Compound 4, i.e., 1,3,4-oxadiazole-2-thione and its corresponding Mannich bases (5-17) were subjected to in silico screening as urease inhibitors, using crystal structure of urease (Protein Data Bank ID: 5FSE) as a model enzyme. Furthermore, the targeted compounds were evaluated for their in vitro urease inhibition and anti-oxidant activities using thiourea and propyl gallate as standards, respectively.

Results: The docking score of targeted compounds predicted that they are promising urease inhibitors. Subsequently, in vitro studies on Jack bean urease supported the results from virtual screening, and found compounds $4,5,9,10,12,13,14$ and 15 very potent urease inhibitors with half-maximal inhibitory concentration $\left(I C_{50}\right)$ values in the range of $5.93 \pm 0.13$ to $9.76 \pm 0.11$, relative to thiourea $\left(I C_{50}=21.25 \pm\right.$ 0.15). Compounds $4-6$, and compounds $12-17$ also exhibited higher antioxidant activities than propyl gallate.
\end{abstract}

Conclusion: In view of their potent urease inhibition and antioxidant activities, these structural motifs have potentials as new candidates for the development of anti-ulcer drugs.

Keywords: 1, 3, 4-Oxadiazole-2-thiones, Antioxidant, Molecular docking, Urease inhibition, Anti-ulcer

This is an Open Access article that uses a funding model which does not charge readers or their institutions for access and distributed under the terms of the Creative Commons Attribution License (http://creativecommons.org/licenses/by/4.0) and the Budapest Open Access Initiative (http://www.budapestopenaccessinitiative.org/read), which permit unrestricted use, distribution, and reproduction in any medium, provided the original work is properly credited.

Tropical Journal of Pharmaceutical Research is indexed by Science Citation Index (SciSearch), Scopus, International Pharmaceutical Abstract, Chemical Abstracts, Embase, Index Copernicus, EBSCO, African Index Medicus, JournalSeek, Journal Citation Reports/Science Edition, Directory of Open Access Journals (DOAJ), African Journal Online, Bioline International, Open-J-Gate and Pharmacy Abstracts

\section{INTRODUCTION}

Compounds derived from 1,3,4-oxadiazole-2thione have received attention as new structural motifs for the design and development of novel drugs [1]. Compounds with 1,3,4-oxadiazole-2thiones cores have occupied a specific place in medicinal and synthetic chemistry because of 
their extensive range of biological activities such as antibacterial [2], antifungal, anti-inflammatory, antiviral, anticancer [1], enzyme inhibitor [3], anticonvulsant and anti-diabetic properties [4]. The 1,3,4-oxadiazole nucleus undergoes a variety of chemical reactions such as electrophilic and nucleophilic substitutions, as well as photochemical and thermal reactions [5]. These properties make it a desirable medicinal backbone which can be used to construct biologically-useful molecules. A number of 1, 3, 4-oxadiazole-2-thione derivatives are used in clinical medicine as antiviral, anticancer, antihypertensive and antibiotic agents. These include Raltegravir ${ }^{\circledR}$, Zibotentan ${ }^{\circledR}$, Tiodazosin, Nesapidel and Furamizole [2]. Urea is hydrolyzed to ammonia and carbon dioxide in the presence of urease (urea amidohydrolase) $[6,7]$. The ammonia produced as by-product shows pathogenic-like behavior in animals and humans, leading to hepatic coma, peptic ulcer, hepatic encephalopathy, pyelonephritis and encrustation in the urinary tract [8]. Helicobacter pylori is an acid-sensitive, gram-negative bacterium which survives only in the $\mathrm{pH}$ range of $7-8$. This acidsensitive bacterium is able to thrive in the low $\mathrm{pH}$ environment of the stomach with the help of urease, which is produced in a highly active form and increases the $\mathrm{pH}$ of human stomach through the hydrolysis of urea [9].

Urease is a virulent factor for $H$. pylori and contributes to mucosal damage in the stomach, gastro-duodenal infection, peptic ulcers and gastric cancer [10]. Thus, the inhibition of urease has attracted much attention as potential strategy for designing novel drugs against ulcer. More effective and more potent compounds with a whole new level of safety and specificity are still desired [11]. In this regard, high throughput virtual and in vitro biological assay of molecules to understand their molecular behaviour in specific environments, will aid the identification of potent molecules from a crude cocktail [12]. Recently, 1,3,4-oxadiazole-2-thiones derivatives have been investigated as active jack bean urease inhibitors with promising anti-urease activities [13]. The aim of the current study was to synthesize Mannich bases derived from 1, 3, 4-oxadiazole-2-thione bearing 3, 4, 5-trimethoxy moiety and examine them as potential urease inhibitors and antioxidant agents.

\section{EXPERIMENTAL}

\section{Analytical procedures}

Chemicals and reagents used for the synthesis of target compounds were purchased from Sigma Aldrich and Merck (Lahore, Pakistan). The purity of the synthesized structures and progress of the reactions were monitored using pre-coated silica gel $60 \mathrm{~F}_{254}$ aluminium TLC plates (Merck). Their melting points were measured with Gallenkamp apparatus, while IR spectra were obtained on Bio-Red Merlin or Bruker. The ${ }^{1} \mathrm{H}$ NMR of each synthesized compound was recorded at a frequency $300 \mathrm{MHz}$ on Bruker AM 300 or at a frequency of $500 \mathrm{MHz}$ on Agilent Technologies spectrophotometer using $\mathrm{CDCl}_{3}$ or DMSO- $d_{6}$ as solvent. The $J$ values of the analyzed compounds are presented in Hertz $(\mathrm{Hz})$. The spectra of ${ }^{13} \mathrm{C}-\mathrm{NMR}$ were recorded at a frequency of $75.5 \mathrm{MHz}$ or $125 \mathrm{MHz}$. EIMS spectra were obtained using Agilent TOF-6220 analyzer, while the elements were analyzed on a Perkin Elmer $2400 \mathrm{CHN}$ instrument.

\section{Synthesis of structural motifs}

The strategy for the synthesis of compounds 2 17 is summarized in Scheme 1. Compound 1 (3, 4, 5-trimethoxybenzoic acid) was transformed into ethyl-3, 4, 5-trimethoxybenzoate 2 by refluxing in Ethanol for $10 \mathrm{~h}$ under anhydrous conditions and catalytic amount of concentrated $\mathrm{H}_{2} \mathrm{SO}_{4}$. The ethyl ester 2 was further converted into 3, 4, 5-trimethoxybenzoicacid hydrazide 3 by heating with $80 \%$ hydrazine in ethanol solvent for $5 \mathrm{~h}$ under reflux. The synthesized hydrazide 3 underwent intermolecular cyclization to yield 5(3, 4, 5-trimethoxy phenyl)-1, 3, 4-oxadiazole-2thione 4 with carbon disulphide in alkaline medium, followed by acidification with dilute hydrochloric acid. Compound 4 (1,3,4oxadiazole-2-thione) was reacted with formaldehyde and substituted anilines and amino pyridines to convert it into the respective Mannich bases i.e. 3-[\{(substituted phenyl)amino\}methyl]-5-(3,4,5-

trimethoxyphenyl)-1,3,4-oxadiazole-2-thiones and 3-[\{(pyridin-2-yl)amino\}methyl]-5-(3,4,5trimethoxyphenyl)-1,3,4-oxadiazole-2-thiones.

\section{Synthesis of 3-[\{(substituted phenyl or pyridin-2-yl) amino\} methyl]-5-(3,4,5- trimethoxyphenyl)-1,3,4-oxadiazole-2(3H)- thiones $(5-17)$}

Formalin (37\%, 0.002 moles) and 0.002 moles of relevant amine were reacted with 0.002 moles 5-(3, 4, 5-trimethoxyphenyl)-1, 3, 4-oxadizole-2thiones in ethanol (about $40 \mathrm{ml}$ ), and vortexed for $1-6 \mathrm{~h}$ at $30{ }^{\circ} \mathrm{C}$. The progress of the reaction was monitored by TLC, and at the end, the mixture was cooled overnight. Thereafter, the resultant sediments were recovered by filtration, rinsed in an appropriate solvent and subjected to re-crystallisation in alcohol. 


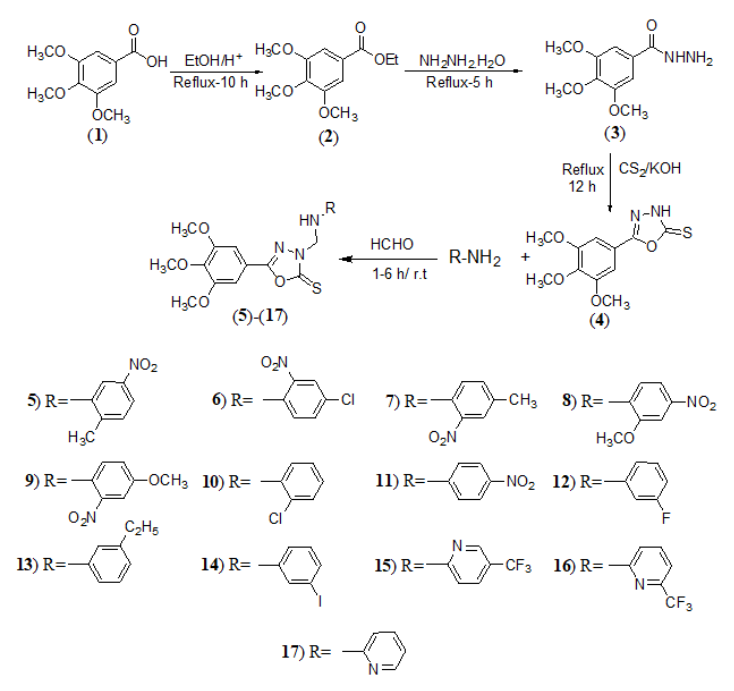

Scheme 1: Synthesis of Mannich Bases derived from 1, 3, 4-oxadiazole-2-thiones.

Compounds 5 - 17 were identified through IR spectroscopy by broad bands in the range $3387-3410 \mathrm{~cm}^{-1}$ which is unique to $-\mathrm{NH}$ group. Peaks were seen between 1615 to $1665 \mathrm{~cm}^{-1}$ obviously from stretches in $\mathrm{C}=\mathrm{N}$, and also between 1145 to $1225 \mathrm{~cm}^{-1}$ because of $\mathrm{C}=\mathrm{S}$ stretches. Product formation was depicted in ${ }^{1} \mathrm{H}$ - NMR spectroscopy by $\mathrm{NH}$ proton peak between 5.4 and $5.9 \mathrm{ppm}$ and a $-\mathrm{CH}_{2}$ peak close to $5.4 \mathrm{ppm}$.

For compounds $6-7$ and $15-17$, the $-\mathrm{NH}$ proton peak appeared near $8.4 \mathrm{ppm}$ (when electron withdrawing group i.e. $\mathrm{NO}_{2}$ was attached to phenyl ring at ortho position with respect to $-\mathrm{NH}$ proton). The $\mathrm{CH}_{2}$ and $\mathrm{NH}$ protons coupled with each other to give rise to doublet and triplet $(\mathrm{J}=6.8-7.5 \mathrm{~Hz})$ respectively. Product formation was confirmed by the appearance of amino methyl signals, since amino methylene is formed at the last stage of the reaction. Aromatic phenyl protons appeared at $6.45-$ $8.16 \mathrm{ppm}$ and de-shielded by the ring current effect. Protons from the $\mathrm{OCH}_{3}$ group resonated between 3.81 and $3.95 \mathrm{ppm}$, whereas methyl protons were found between 2.38 and $2.51 \mathrm{ppm}$ up the field. In ${ }^{13} \mathrm{C}$ - NMR analysis, $\mathrm{CH}_{2}$ peak at $57.6-58.4-\mathrm{ppm}$ confirmed the amino methyl function.

However, this was absent in the reactant 4. These results were strengthened by DEPT spectra which showed different peaks (same or opposite sides of the solvent signal) for different types of carbons. Two significant peaks observed at 176 and $159 \mathrm{ppm}$ due to carbon linkage with sulphur and nitrogen atoms, respectively. The signals of all carbon atoms of the aromatic ring were observed in region $101-153$ ppm downfield. The carbon atoms of methyl and methoxy groups attached to aromatic ring appeared at 17.08 -21.29 ppm and $56.46-61.14$ respectively. Unambiguous confirmation of the structure (4) was obtained by X-ray crystallographic analysis [14].

\section{Urease assay and assessment of inhibition}

Compounds $4-17$ were screened for ability to inhibit urease in vitro by the phenol hypochlorite method described by Weatherburn [15]. In 96well plate, $25 \mu \mathrm{l}$ jack bean urease enzyme solution was incubated with reaction mixture containing $55 \mu \mathrm{l}$ of phosphate buffer, $5 \mu \mathrm{l}$ of test compound followed by $15 \mu \mathrm{l}$ of $100 \mathrm{mM}$ urea at $37^{\circ} \mathrm{C}$ for $15 \mathrm{~min}$. For colour appearance, $100 \mu \mathrm{l}$ of phenol-hypochlorite reagent was added in each well followed by incubation at $37^{\circ} \mathrm{C}$ for 30 min. The results were evaluated by calculating change in absorbance taken by 96 wells plate reader at $620 \mathrm{~nm}$ and by using formula $100-$ [(OD of test / OD of control $) \times 100$. The entire assay was performed in triplicate at $\mathrm{pH} 7$ and using thiourea as standard inhibitor of urease.

\section{Determination of antioxidant activity}

DPPH scavenging activity was measured using a slight modification of the method in the literature $[16,17]$.

\section{Docking studies}

The interactions of 1,3,4-oxadiazole-2-thione derivatives with urease were studied theoretically through docking experiments, which were performed using AutoDockTools version 1.5.6 (ADT) software [18]. Default ten docking runs were set for all compounds to observe their interactions with active site of urease molecule. Ligand and receptor binding energy/affinity were calculated with ADT software package by using search parameter Genetic Algorithm. Ligand structure was optimized using Avogadro software [19].

Sporosarcina pasteurii (formerly Bacillus pasteurii) urease (SPU) [20] file with PDB code: 5FSE (contain three protein chains designated as $A, B$, and $C$ ) was downloaded in PDB format from RCSB Protein Data Bank, which was further processed for docking studies by isolating chain- $C$ which play vital role in urease activity and contain active pockets [21]. Chain-A and chain-B along with non-protein fragments e.g. ligand and solvent molecules were 
removed using BIOVIA Discovery Studio Visualizer v16.1.0.15350.

Docking analysis was done using ADT. Hydrogens were added and non-polar hydrogen were merged in receptor molecule (5FSE chainC). Moreover, the Kollman charges were also added to the receptor molecule. For docking, the receptor macromolecule was considered as a rigid structure. AutoGrid program was used for generating $58 \times 60 \times 70 \AA$ grid points and 0.254 A spacing for affinity (grid) maps, while ADT default parameter and functions, along with all possible torsions of the ligand molecule were used in the electrostatic, bonding and energy calculations. Lamarckian genetic algorithm (LGA 4.2) was used for docking simulations. Ten different binding conformations of ligand with receptor were obtained with their respective binding energies/affinities. The pose with strongest binding affinity to receptor (out of the ten) was chosen as the most stable one and further employed in the post-docking analysis.

\section{Statistical analysis}

Biological studies were performed at five different concentrations in order to calculate $I_{50}$ values using linear regression method with Graphpad Prism 5. The results are shown as mean \pm SEM $(n=3)$.

\section{RESULTS}

\section{3-[\{(2-Methyl-5-nitrophenyl)amino\}methyl]-5- (3,4,5-trimethoxyphenyl)-1,3,4-oxadiazole- 2(3H)-thione (5)}

The reaction time was $2.5 \mathrm{~h}$, resulting in a yield of $81 \%$. The product was a light yellow solid; melting point $=206-208{ }^{\circ} \mathrm{C}$. IR $\left(\mathrm{cm}^{-1}\right) ; 3398$ $(\mathrm{NH}), 2938$ (Ar- $\mathrm{CH}$, aromatic), $2831\left(\mathrm{CH}_{2}\right.$, aliphatic), 1622 ( $\mathrm{C}=\mathrm{N}$, oxadiazole), 1602, 1581 $\left(\mathrm{C}=\mathrm{C}\right.$, aromatic), $1508\left(\mathrm{NO}_{2}\right), 1209,1149$, (C-OC), $1142(\mathrm{C}=\mathrm{S}) \cdot{ }^{1} \mathrm{H}-\mathrm{NMR}\left(\mathrm{CDCl}_{3}, 500 \mathrm{MHz}, \delta\right.$ ppm); $8.25(\mathrm{~d}, 1 \mathrm{H}, \mathrm{Ar}-\mathrm{H} J=2 \mathrm{~Hz}), 7.71(\mathrm{dd}, 1 \mathrm{H}$, Ar-H, J = 7.5 Hz, $2 \mathrm{~Hz}), 7.35(\mathrm{~s}, 2 \mathrm{H}, \mathrm{Ar}-\mathrm{H}), 7.29$ $(\mathrm{d}, 1 \mathrm{H}, J=8 \mathrm{~Hz}), 5.73\left(\mathrm{~d}, 2 \mathrm{H}, \mathrm{CH}_{2}, J=7.5 \mathrm{~Hz}\right)$, $5.44(\mathrm{t}, 1 \mathrm{NH}, J=7.5 \mathrm{~Hz}), 4.02\left(\mathrm{~s}, 6 \mathrm{H}, \mathrm{OCH}_{3}\right)$, 3.92( $\left(\mathrm{s}, 3 \mathrm{H}, \mathrm{OCH}_{3}\right), 2.38\left(\mathrm{~s}, 3 \mathrm{H}, \mathrm{CH}_{3}\right) \cdot{ }^{13} \mathrm{C}-\mathrm{NMR}$ $\left(\mathrm{CDCl}_{3}, 125 \mathrm{MHz}, \delta \mathrm{ppm}\right) ; 176.51(\mathrm{C}=\mathrm{S})$, $159.36(\mathrm{C}=\mathrm{N}), 153.91(2 \mathrm{C}), 147.78,143.32$, $142.85,131.01,130.97,117.03,114.68,106.75$, $103.79(2 \mathrm{C}) 61.14\left(1 \mathrm{C}, \mathrm{OCH}_{3}\right), 58.23\left(1 \mathrm{C}, \mathrm{CH}_{2}\right)$, $56.54\left(2 \mathrm{C}, \mathrm{OCH}_{3}\right), 17.80\left(1 \mathrm{C}, \mathrm{CH}_{3}\right)$. HRMS (Esi): $m / z$ calculated for $\mathrm{C}_{19} \mathrm{H}_{20} \mathrm{~N}_{4} \mathrm{O}_{6} \mathrm{~S}(\mathrm{M}+\mathrm{Na})^{+}$: 455.0996; found: 455.1001. Analytically calculated for $\mathrm{C}_{19} \mathrm{H}_{20} \mathrm{~N}_{4} \mathrm{O}_{6} \mathrm{~S}: \mathrm{C}=52.77 ; \mathrm{H}=4.66$; $\mathrm{N}=12.96$; found: $\mathrm{C}=52.98 ; \mathrm{H}=4.53 ; \mathrm{N}=12.71$
3[\{(4-Chloro-2-nitrophenyl)amino\}methyl]-5(3,4,5-trimethoxyphenyl)-1,3,4-oxadiazole2(3H)-thione (6)

The reaction time was $5.4 \mathrm{~h}$, resulting in a yield of $69 \%$, The product was a yellow solid; melting point $=178-180{ }^{\circ} \mathrm{C}, \mathrm{IR}\left(\mathrm{cm}^{-1}\right) ; 3406(\mathrm{NH}), 2945$ (Ar-CH, aromatic), $2869\left(\mathrm{CH}_{2}\right.$, aliphatic), 1629 (C $=\mathrm{N}$, oxadiazole $), 1602,1553(\mathrm{C}=\mathrm{C}$, aromatic $)$, $1184(\mathrm{C}=\mathrm{S}), 1166,1141 \quad(\mathrm{C}-\mathrm{O}-\mathrm{C}) .{ }^{1} \mathrm{H}$ $\mathrm{NMR}\left(\mathrm{CDCl}_{3}, 500 \mathrm{MHz}, \delta \mathrm{ppm}\right) ; 8.75$ (t, $1 \mathrm{NH}, J=$ $7.5 \mathrm{~Hz}) 8.20(\mathrm{~d}, 1 \mathrm{H}, J=2.5 \mathrm{~Hz}), 7.50(\mathrm{~s}, 2 \mathrm{H}, \mathrm{Ar}-$ $\mathrm{H}), 7.15-7.11(\mathrm{~m}, 2 \mathrm{H}, \mathrm{Ar}-\mathrm{H}), 5.66\left(\mathrm{~d}, 2 \mathrm{H}, \mathrm{CH}_{2}, \mathrm{~J}\right.$ $=7.5 \mathrm{~Hz}), 3.91\left(\mathrm{~s}, 9 \mathrm{H}, \mathrm{OCH}_{3}\right) .{ }^{13} \mathrm{C}-\mathrm{NMR}\left(\mathrm{CDCl}_{3}\right.$, $125 \mathrm{MHz}, \delta \mathrm{ppm}) ; 176.47(\mathrm{C}=\mathrm{S}), 159.21(\mathrm{C}=\mathrm{N})$, 153.77 (2C), 142.08, 140.71, 136.56, 133.56, $126.21,123.53,116.77,116.73,103.87$ (2C),, $61.07\left(1 \mathrm{C}, \mathrm{OCH}_{3}\right), 58.21\left(1 \mathrm{C}, \mathrm{CH}_{2}\right), 56.46(2 \mathrm{C}$, $\left.\mathrm{OCH}_{3}\right) . \mathrm{El}, \mathrm{m} / \mathrm{z}\left(\mathrm{I}_{\mathrm{rel}}, \%\right): 475[\mathrm{M}+\mathrm{Na}]^{+}(35), 402.2$ (38),455.2 (12), $455.2 \quad(15), \quad 291.0 \quad$ (100), 269.1(25), 229.1 (20), 195.1 (15). Analitically calculated for $\mathrm{C}_{18} \mathrm{H}_{17} \mathrm{ClN}_{4} \mathrm{O}_{6} \mathrm{~S}: \mathrm{C}=47.74 ; \mathrm{H}=$ 3.78; $\mathrm{N}=12.37$; found: $\mathrm{C}=47.89 ; \mathrm{H}=3.72 ; \mathrm{N}=$ 12.51 .

\section{3-[\{(4-Methyl-2-nitrophenyl)amino\}methyl]-5- (3,4,5-trimethoxyphenyl)-1,3,4-oxadiazole- 2(3H)-thione.(7)}

The reaction time was $3 \mathrm{~h}$, resulting in a yield of $79 \%$; The product was a yellow solid; melting point $=210-212^{\circ} \mathrm{C}$, IR $\left(\mathrm{cm}^{-1}\right) ; 3402(\mathrm{NH}), 2912$ (Ar-CH, aromatic), $2864\left(\mathrm{CH}_{2}\right.$, aliphatic), 1615 (C $=\mathrm{N}$, oxadiazole $), 1640,1582(\mathrm{C}=\mathrm{C})$ aromatic skeleton) $1506\left(\mathrm{NO}_{2}\right), 1207(\mathrm{C}=\mathrm{S})$ 1202, 1126, (C-O-C). ${ }^{1} \mathrm{H}-\mathrm{NMR}\left(\mathrm{DMSO}-d_{6}, 500 \mathrm{MHz}, \delta\right.$ ppm); 8.70 (t, NH, J=6.8 Hz), $7.93(\mathrm{~d}, 1 \mathrm{H}, \mathrm{Ar}-\mathrm{H}$, $J=2 \mathrm{~Hz}$ ), 7.46 (dd, $1 \mathrm{H}, \mathrm{Ar}-\mathrm{H}, J=8 \mathrm{~Hz}, 2 \mathrm{~Hz}$ ), 7.34 (s, 2H, Ar-H), 7.18 (d, $1 \mathrm{H}, \mathrm{Ar}-\mathrm{H}, J=8 \mathrm{~Hz}$ ), $5.72\left(\mathrm{~d}, 2 \mathrm{H}, \mathrm{CH}_{2}, J=7 \mathrm{~Hz}\right), 3.88\left(\mathrm{~s}, 6 \mathrm{H}, \mathrm{OCH}_{3}\right)$, $3.85\left(\mathrm{~s}, 3 \mathrm{H}, \mathrm{OCH}_{3}\right), 2.51\left(\mathrm{~s}, 3 \mathrm{H}, \mathrm{CH}_{3}\right) \cdot{ }^{13} \mathrm{C}-\mathrm{NMR}$ (DMSO - $\left.d_{6}, 125 \mathrm{MHz}, \delta \mathrm{ppm}\right) ; 175.55(\mathrm{C}=\mathrm{S})$, $158.92(\mathrm{C}=\mathrm{N}), 153.39(2 \mathrm{C}), 141.05,140.09$, 137.64, 132.66, 127.25, 125.52, 116.84, 115.37, $103.54(2 \mathrm{C}), 60.18\left(1 \mathrm{C}, \mathrm{OCH}_{3}\right), 56.74\left(1 \mathrm{C}, \mathrm{CH}_{2}\right)$, $56.13\left(2 \mathrm{C}, \mathrm{OCH}_{3}\right), 19.31\left(1 \mathrm{C}, \mathrm{CH}_{3}\right)$. HRMS (Esi): $m / z$ calculated for $\mathrm{C}_{19} \mathrm{H}_{20} \mathrm{~N}_{4} \mathrm{O}_{6} \mathrm{~S}(\mathrm{M}+\mathrm{Na})^{+}$: 455.0996; found: 455.1003. Analitically calculated for $\mathrm{C}_{19} \mathrm{H}_{20} \mathrm{~N}_{4} \mathrm{O}_{6} \mathrm{~S}: \mathrm{C}=52.77 ; \mathrm{H}=4.66$; $\mathrm{N}=12.96$; found: $\mathrm{C}=52.95 ; \mathrm{H}=4.59 ; \mathrm{N}=$ 12.68 .

The detailed synthesis and spectroscopic and spectrometric data of compounds $8-17$ are provided in supplementary material.

\section{Docking analysis data}

Docking scores (Table 1) i.e. kinase inhibition values (KI), binding energy and interactions of 
the synthesized compounds $4-17$ in active pocket of receptor urease enzyme (PDB ID: 5FSE Chain-C) predicted these compounds as promising urease inhibitors, which was further supported by the experimental results (Table 2). In docking studies, it was observed that compound 5 (Figure 1-2) and $\mathbf{1 3}$ form hydrogen bond with HIS323 (Table 3 ) which is next to CYS322 blocked by quinone known as urease inhibitor [21].

\section{Urease inhibition}

The virtual screening of compounds $4-\mathbf{1 7}$ as promising urease inhibitors was further supported by their in vitro urease inhibition against Jack bean urease in an assay using standard inhibitor thiourea, in which thiourea had an $\mathrm{IC}_{50}$ value of $21.25 \pm 0.15 \mu \mathrm{M}$. Almost all the synthesized derivatives (twelve out of fourteen) of this series exhibited remarkable urease inhibitory potency superior to that of thiourea (Table 2). The interaction of compound $\mathbf{5}$ (representative) with the active site of urease is depicted in Figure 1, while the active site groups involved in hydrogen bonding are shown in Figure 2.

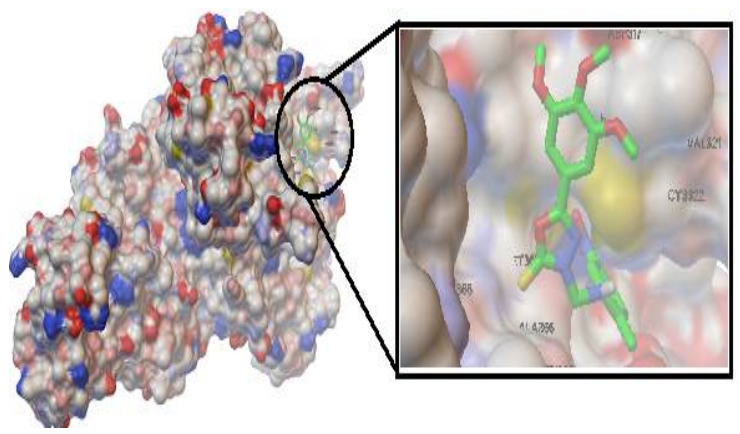

Figure 1: Ligand 5 represented with stick structure inside the active site of urease (PDB code: 5FSE) depicted in MMS form [22].

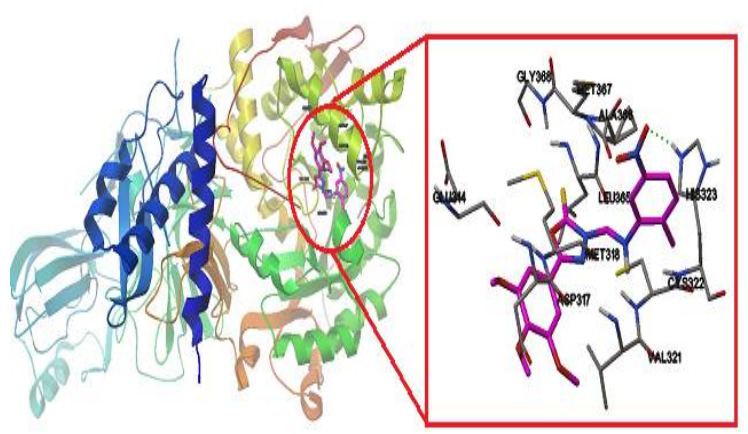

Figure 2: Hydrogen bonding (represented by dotted line) and interacting sites of urease (PDB code: 5FSE Chain-C) with ligand $\mathbf{5}$ represented by structure contain magenta colour stick[18]
Table 2: Inhibitory activities of 1, 3, 4-oxadiazole derivatives $4-17$ against Jack bean urease

\begin{tabular}{lll}
\hline Compound & $\begin{array}{l}\text { \% Inhibition at } \\
\mathbf{0 . 2 5} \mathbf{~ m M}\end{array}$ & $\mathbf{I}_{\mathbf{5 0}}(\boldsymbol{\mu M})$ \\
\hline $\mathbf{4}$ & $97.73 \pm 0.17$ & $5.93 \pm 0.13$ \\
$\mathbf{5}$ & $97.18 \pm 0.21$ & $6.35 \pm 0.15$ \\
$\mathbf{6}$ & $45.63 \pm 0.12$ & - \\
$\mathbf{7}$ & $92.64 \pm 0.23$ & $27.64 \pm 0.17$ \\
$\mathbf{8}$ & $97.14 \pm 0.18$ & $12.43 \pm 0.14$ \\
$\mathbf{9}$ & $97.27 \pm 0.24$ & $8.54 \pm 0.17$ \\
$\mathbf{1 0}$ & $97.83 \pm 0.15$ & $9.76 \pm 0.11$ \\
$\mathbf{1 1}$ & $96.12 \pm 0.17$ & $15.23 \pm 0.12$ \\
$\mathbf{1 2}$ & $97.15 \pm 0.19$ & $9.15 \pm 0.16$ \\
$\mathbf{1 3}$ & $97.46 \pm 0.15$ & $6.38 \pm 0.12$ \\
$\mathbf{1 4}$ & $97.86 \pm 0.19$ & $9.24 \pm 0.13$ \\
$\mathbf{1 5}$ & $97.13 \pm 0.22$ & $7.36 \pm 0.15$ \\
$\mathbf{1 6}$ & $97.34 \pm 0.15$ & $16.2 \pm 0.11$ \\
$\mathbf{1 7}$ & $97.25 \pm 0.19$ & $15.82 \pm 0.13$ \\
\hline Thiourea & $98.21 \pm 0.18$ & $21.25 \pm 0.15$ \\
\hline
\end{tabular}

\section{Antioxidant activity}

The DPPH radical scavenging activity is a standard assay in antioxidant activity measurements. In the current study, the standard antioxidant compounds propyl gallate and quercetin were used as positive controls for comparison with the tested compounds. The antioxidant activities of the synthesized compounds are shown in Table 4.

Table 4: Antioxidant activity of 1, 3, 4-oxadiazoles derivatives $4-17$ by DPPH radical scavenging method

\begin{tabular}{lcc}
\hline Compound & \multicolumn{2}{c}{ Antioxidant activity } \\
\cline { 2 - 3 } & $\begin{array}{c}\text { \% Inhibition at } \mathbf{0 . 5} \\
\mathbf{~ m M ~}\end{array}$ & IC $_{50}(\boldsymbol{\mu M})$ \\
\hline $\mathbf{4}$ & $87.24 \pm 0.21$ & $37.63 \pm 0.15$ \\
$\mathbf{5}$ & $85.54 \pm 0.23$ & $41.27 \pm 0.17$ \\
$\mathbf{6}$ & $85.79 \pm 0.18$ & $42.53 \pm 0.13$ \\
$\mathbf{7}$ & $17.19 \pm 0.14$ & - \\
$\mathbf{8}$ & $38.29 \pm 0.17$ & - \\
$\mathbf{9}$ & $42.39 \pm 0.15$ & - \\
$\mathbf{1 0}$ & $16.53 \pm 0.15$ & - \\
$\mathbf{1 1}$ & $86.87 \pm 0.23$ & $52.42 \pm 0.18$ \\
$\mathbf{1 2}$ & $86.42 \pm 0.21$ & $42.54 \pm 0.17$ \\
$\mathbf{1 3}$ & $86.51 \pm 0.19$ & $42.16 \pm 0.15$ \\
$\mathbf{1 4}$ & $86.14 \pm 0.23$ & $43.28 \pm 0.18$ \\
$\mathbf{1 5}$ & $87.38 \pm 0.22$ & $32.42 \pm 0.18$ \\
$\mathbf{1 6}$ & $88.29 \pm 0.18$ & $44.93 \pm 0.15$ \\
$\mathbf{1 7}$ & $86.21 \pm 0.19$ & $35.15 \pm 0.15$ \\
Quercetin & $85.65 \pm 0.15$ & $12.24 \pm 0.12$ \\
Propyl gallate & $80.71 \pm 0.14$ & $46.32 \pm 0.11$ \\
\hline
\end{tabular}

\section{DISCUSSION}

In silico studies showed that all the ligands interact with active site and have ability to occupy it like quinone. Predicted hydrogen bonding (Table 3) also forecast that these molecules have ability to inhibit urease activity permanently by bonding to the active site, as depicted by representative molecule 5 . 
Table 1: Docking scores of compounds $\mathbf{4}-\mathbf{1 7}$ with receptor molecule (PDB code: 5FSE) calculated through ADT [18]

\begin{tabular}{lcccccc}
\hline Compound & $\begin{array}{c}\text { Ligand structure optimization } \\
\text { energy KJ/mol }\end{array}$ & $\begin{array}{c}\text { Binding Energy } \\
\text { (kcal/mole) }\end{array}$ & $\mathbf{k l}$ (uM) & $\begin{array}{c}\text { Inter-mol. } \\
\text { Energy }\end{array}$ & $\begin{array}{c}\text { Internal } \\
\text { Energy }\end{array}$ & $\begin{array}{c}\text { Torsional } \\
\text { Energy }\end{array}$ \\
\hline $\mathbf{4}$ & 297.43 & -4.45 & 546.34 & -6.31 & -0.63 & 1.19 \\
$\mathbf{5}$ & 425.08 & -4.71 & 355.57 & -7.09 & -0.97 & 2.39 \\
$\mathbf{6}$ & 461.68 & -4.6 & 426.72 & -6.98 & -1.61 & 2.39 \\
$\mathbf{7}$ & 528.13 & -4.41 & 590.29 & -6.79 & -1.58 & 2.39 \\
$\mathbf{8}$ & 481.14 & -4.17 & 880.27 & -6.85 & -1.6 & -2.68 \\
$\mathbf{9}$ & 500.66 & -4.79 & 308.28 & -7.47 & -1.47 & 2.68 \\
$\mathbf{1 0}$ & 378.61 & -5.55 & 85.76 & -7.64 & -1.17 & 2.09 \\
$\mathbf{1 1}$ & 426.80 & -4.51 & 497.39 & -6.89 & -1.22 & 2.39 \\
$\mathbf{1 2}$ & 279.12 & -5.57 & 82.39 & -7.66 & -1.09 & 2.09 \\
$\mathbf{1 3}$ & 300.62 & -5.56 & 83.55 & -7.95 & -1.15 & 2.39 \\
$\mathbf{1 4}$ & 290.75 & -5.63 & 74.5 & -7.72 & -1.05 & 2.09 \\
$\mathbf{1 5}$ & 160.26 & -5.24 & 144.9 & -7.62 & -0.99 & 2.39 \\
$\mathbf{1 6}$ & 361.67 & -5.32 & 125.36 & -7.71 & -1.44 & 2.39 \\
$\mathbf{1 7}$ & 121.20 & -4.43 & 569.55 & -6.51 & -0.99 & 2.09 \\
\hline
\end{tabular}

Table 3: Receptor molecule (PDB code: 5FSE Chain-C) active site interactions with compounds 4 - $\mathbf{1 7}$ as predicted through ADT [18]

\begin{tabular}{|c|c|c|}
\hline $\begin{array}{l}\text { Ligand/ } \\
\text { Compound }\end{array}$ & $\begin{array}{l}\text { Groups involved in } \\
\text { hydrogen bonding } \\
\text { with Ligand }\end{array}$ & Active pocket groups involved in interaction with ligand \\
\hline 4 & & $\begin{array}{l}\text { GLU314, MET318, LEU319, CYS322, ALA366, MET367, GLY368, } \\
\text { ARG369 }\end{array}$ \\
\hline 5 & HIS323 & $\begin{array}{l}\text { GLU314, ASP317, MET318, VAL321, CYS322, HIS323, LEU365, } \\
\text { ALA366, MET367, GLY368 }\end{array}$ \\
\hline 6 & HIS323 & $\begin{array}{l}\text { LYS169, GLU314, ASP317, MET318, LEU319, VAL321, CYS322, } \\
\text { HIS323, ALA366, MET367, }\end{array}$ \\
\hline 7 & GLY368 & $\begin{array}{l}\text { ASP313, GLU314, ASP317, MET318, VAL321, CYS322, LEU365, } \\
\text { ALA366, GLY368 }\end{array}$ \\
\hline 8 & & $\begin{array}{l}\text { LYS169, GLU314, ASP317, MET318, LEU319, VAL321, CYS322, } \\
\text { HIS323, ALA366, MET367 }\end{array}$ \\
\hline 9 & GLY368 & GLU314, ASP317, MET318, VAL321, CYS322, LEU365, ALA366, \\
\hline 10 & & $\begin{array}{l}\text { GLU314, ASP317, MET318, VAL321, CYS322, HIS323, ARG339, } \\
\text { LEU365, ALA366, MET367 }\end{array}$ \\
\hline 11 & HIS323 & $\begin{array}{l}\text { GLU314, ASP317, MET318, LEU319, VAL321, CYS322, HIS323, } \\
\text { ARG339, ALA366 }\end{array}$ \\
\hline 12 & & $\begin{array}{l}\text { LYS169, GLU314, ASP317, MET318, LEU319, VAL321, CYS322, } \\
\text { ALA366 }\end{array}$ \\
\hline 13 & HIS323 & $\begin{array}{l}\text { GLU314, ASP317, MET318, VAL321, CYS322, HIS323, ARG339, } \\
\text { ALA366, MET367 }\end{array}$ \\
\hline 14 & & $\begin{array}{l}\text { GLU314, MET318, VAL321, CYS322, HIS323, LEU365, ALA366, } \\
\text { MET367, GLY368 }\end{array}$ \\
\hline 15 & & $\begin{array}{l}\text { LYS169, GLU314, ASP317, MET318, LEU319, CYS322, HIS323, } \\
\text { ALA366, MET367 }\end{array}$ \\
\hline 16 & & $\begin{array}{l}\text { GLU314, MET318, VAL321, CYS322, LEU365, ALA366, MET367, } \\
\text { GLY368 }\end{array}$ \\
\hline 17 & & $\begin{array}{l}\text { LYS169, GLU314, ASP317, MET318, VAL321,LEU365, ALA366, } \\
\text { GLY368, ARG369 }\end{array}$ \\
\hline
\end{tabular}

The urease inhibition activities of all the synthesized compounds ranged in $\mathrm{IC}_{50}$ values from $5.93 \mu \mathrm{M}$ to $27.64 \mu \mathrm{M}$. The results indicate that 3, 4, 5-trimethoxy-substituted benzene next to oxadiazole ring shows excellent urease inhibition. Among the investigated compounds, compound 4 bearing methoxy groups at 3,4,5 positions in the benzene ring, was observed as the most effective urease inhibitor, with $I_{50}$ value of $5.93 \pm 0.13 \mu \mathrm{M}$. Compound 5 bearing methyl group at position 2, and nitro group at position 5 of the benzene ring showed stronger inhibitory activity close to $6.35 \mu \mathrm{M}$, when compared with compound 7 with a methyl group at position 4 and nitro group at position 2, which was less active.

Compound 9 bearing electron-donating methoxy group at $p$-position and electron-withdrawing nitro group at 0 -position was slightly more active $\left(\mathrm{IC}_{50}\right.$ value of $\left.8.54 \pm 0.17 \mu \mathrm{M}\right)$ than compounds 8 and 11 having electron-donating methoxy group 
at $o$ - and electron-withdrawing nitro group at $p$ positions. Compounds 12, 13 and 14 with fluoro, ethyl and ido substitutions, respectively at meta position, showed good activity, with $\mathrm{IC}_{50}$ ranging from $6.38 \pm 0.12$ to $9.24 \pm 0.13 \mu \mathrm{M}$. Compound 15 bearing trifluoromethyl group at 5 position was more active $\left(\mathrm{IC}_{50}\right.$ value $\left.=7.36 \pm 0.15 \mu \mathrm{M}\right)$ than compound 16 with trifluoromethyl group at positions 6 of substituted pyridine ring in the parent, 1,3,4-oxadiazole-2-thione core.

The antioxidant activities of the most effective compounds ranged from $32.42 \pm 0.18$ to $45.28 \pm$ $0.18 \mu \mathrm{M}$. The 3, 4, 5-trimethoxy-substituted benzene next to oxadiazole ring showed excellent antioxidant activity. Compounds 15 and 17 bearing substituted pyridine ring next to amino methyl group in parent 1,3,4-oxadiazole-2-thione core exhibited excellent antioxidant activities with $\mathrm{IC}_{50}$ values of $32.42 \pm 0.18 \mu \mathrm{M}$ and $35.15 \pm 0.15$ $\mu \mathrm{M}$, respectively when compared with standard propyl gallate $\left(\mathrm{IC}_{50}=46.32 \pm 0.11 \mu \mathrm{M}\right)$. Similarly, compounds 12, 13, and 14 having fluoro, ethyl and ido substitutions, respectively at meta position in substituted phenyl rings showed good antioxidant potencies, with $\mathrm{IC}_{50}$ in the range of $42.54 \pm 0.17$ to $43.28 \pm 0.18 \mu \mathrm{M}$, relative to standard.

\section{CONCLUSION}

Thirteen derivatives of $1,3,4$-oxadiazole-2thiones 5 - 17 have been synthesized successfully, with good yields, and thereafter comprehensively characterized. In silico and in vitro data indicate that they are potent urease inhibitors. The synthesized compounds also display good antioxidant activities. On the basis of these findings, these compounds possess potentials as candidates for the development of new anti-ulcer drugs.

\section{DECLARATIONS}

\section{Acknowledgement}

Higher Education Commission of Pakistan is acknowledged for financial support.

\section{Conflict of interest}

No conflict of interest is associated with this work.

\section{Contribution of authors}

The authors declare that this work was done by the authors named in this article and all liabilities pertaining to claims relating to the content of this article will be borne by them.

\section{REFERENCES}

1. Aboraia AS, Abdel-Rahman HM, Mahfouz NM, El-Gendy MA. Novel 5-(2- hydroxyphenyl)-3-substituted-2,3dihydro-1,3,4-oxadiazole-2-thione derivatives: Promising anticancer agents. Bioorg Med Chem 2006; 14(4): 12361246.

2. Luo Y, Liu Z-J, Chen G, Shi J, Li J-R, Zhu H-L. 1,3,4Oxadiazole derivatives as potential antitumor agents: discovery, optimization and biological activity valuation. MedChemComm 2016; 7(2): 263-271.

3. Saitoh M, Kunitomo J, Kimura E, Hayase Y, Kobayashi $H$, Uchiyama $N$, Kawamoto $T$, Tanaka $T$, Mol $C D$, Dougan DR, Textor GP, Snell GP, Itoh F. Design, Synthesis and Structure-Activity Relationships of 1,3,4Oxadiazole Derivatives as Novel Inhibitors of Glycogen Synthase Kinase-3ß. Bioorg Med Chem 2009; 17: 20172029.

4. Saitoh M, Kunitomo J, Kimura E, Iwashita $H$, Uno $Y$, Onishi T, Uchiyama N, Kawamoto T, Tanaka T, Mol CD, Dougan DR, Textor GP, Snell GP, Takizawa M, Itoh F, Kori M. 2-\{3-[4-(Alkylsulfinyl)phenyl]-1-benzofuran-5-yl\}5-methyl-1,3,4-oxadiazole Derivatives as Novel Inhibitors of Glycogen Synthase Kinase-3 $\beta$ with Good Brain Permeability. J Med Chem 2009; 52(20): 62706286.

5. Liras S, Allen MP, Segelstein BE. A mild method for the preparation of 1,3,4-oxadiazoles: Triflic anhydride promoted cyclization of diacylhydrazines. Synth Commun 2000; 30(3): 437-443.

6. Ambrose JF, Kistiakowsky GB, Kridl AG. Inhibition of urease by sulfur compounds. J Am Chem Soc 1950; 72: 317-321.

7. Krajewska B, Zaborska W. Double mode of inhibitioninducing interactions of 1,4-naphthoquinone with urease. Arylation vs oxidation of enzyme thiols. Bioorg Med Chem 2007; 15: 4144-4151.

8. Algood HMS, Cover TL. Helicobacter pylori persistence: an overview of interactions between $\mathrm{H}$. pylori and host immune defenses. Clin Microbiol Rev 2006; 19: 597613.

9. Graham DY, Fischbach L. Helicobacter pylori treatment in the era of increasing antibiotic resistance. Gut 2010; 59: 1143-1153.

10. Karplus PA, Pearson MA, Hausinger RP. 70 Years of crystalline urease: what have we learned? Acc Chem Res 1997; 30: 330-337.

11. Krishnamurthy $P$, Parlow M, Zitzer JB, Vakil NB, Mobley HLT, Levy M, Phadnis SH, Dunn BE. Helicobacter pylori containing only cytoplasmic urease is susceptible to acid. Infect Immun 1998; 66: 5060-5066.

12. Yoshiki Higashijima, Tetsuhiro Tanaka, Masaomi Nangaku. Structure-based drug design for hypoxiainducible factor prolyl-hydroxylase inhibitors and its therapeutic potential for the treatment of erythropoiesis-

Trop J Pharm Res, January 2018; 17(1): 133 
stimulating agent-resistant anemia: raising expectations for exploratory clinical trials. Expert Opinion on Drug Discovery 2013; 8(8): 965-976.

13. Hanif M, Shoaib K, Saleem M, Hasan Rama N, Zaib S, lqbal J. Synthesis, Urease Inhibition, Antioxidant, Antibacterial, and Molecular Docking Studies of 1,3,4Oxadiazole Derivatives. ISRN Pharmacology 2012; 2012: 928901-928909.

14. Saeed A, Akram M, Rauf A, Bolte M. 5-(3,4,5Trimethoxyphenyl)-1,3,4-oxadiazole-2(3H)-thione. Acta Crystallographica Section E 2010; 66(8): 01911-01911.

15. Naureen S, Chaudhry F, Asif N, Munawar MA, Ashraf M, Nasim FH, Arshad H, Khan MA. Discovery of indolebased tetraarylimidazoles as potent inhibitors of urease with low antilipoxygenase activity. European journal of medicinal chemistry 2015; 102: 464-470.

16. Alam MN, Bristi NJ, Rafiquzzaman M. Review on in vivo and in vitro methods evaluation of antioxidant activity. Saudi Pharmaceutical Journal 2013; 21(2): 143-152.

17. Gupta AK, Kalpana S, Malik JK. Synthesis and In Vitro Antioxidant Activity of New 3-Substituted-2-Oxindole
Derivatives. Indian Journal of Pharmaceutical Sciences 2012; 74(5): 481-486.

18. Sanner MF. Python: A Programming Language for Software Integration and Development. J Mol Graphics Mod 1999; 17: 57-61.

19. Hanwell MD, Curtis DE, Lonie DC, Vandermeersch $T$, Zurek E, Hutchison GR. Avogadro: an advanced semantic chemical editor, visualization, and analysis platform. Journal of Cheminformatics 2012; 4(1): 1-17.

20. Benini S, Cianci M, Mazzei L, Ciurli S. Fluoride inhibition of Sporosarcina pasteurii urease: structure and thermodynamics. J Biol Inorg Chem 2014; 19: 12431261.

21. Mazzei L, Cianci M, Musiani F, Lente G, Palombo M, Ciurli S. Inactivation of urease by catechol: Kinetics and structure. Journal of Inorganic Biochemistry 2017; 166(Supplement C): 182-189.

22. Sanner MF, Spehner JC, Olson AJ. Reduced surface: an efficient way to compute molecular surfaces. Biopolymers 1996; 38(3): 305-320. 